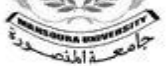

Mansoura University

Faculty of Tourism and Hotels

\title{
THE ROLE OF SOUVENIRS AND HANDICRAFTS IN ACHIEVING TOURISTS' SATISFACTION \\ "APPLIED ON LUXOR CITY"
}

\begin{abstract}
By
Dr/ Noha Abou El Gheit Dawood Dr/ Rania Mohamed Bahaa El- Din

Lecturer of Tourism management- Ass.Prof of Tourism management-

Faculty of Tourism and Hotels - $\quad$ Faculty of Tourism and Hotels -

Luxor University

Mansoura University
\end{abstract}

ISSUE NO. 6, DECEMBER. 2019 
The role of souvenirs and handicrafts in achieving tourists' satisfaction "Applied on Luxor city" 


\section{THE ROLE OF SOUVENIRS AND HANDICRAFTS IN ACHIEVING TOURISTS' SATISFACTION "APPLIED ON LUXOR CITY"}

Dr/ Noha Abou El Gheit Dawood ${ }^{1}$

| Dr/ Rania Mohamed Bahaa El-Din²

\section{Abstract:}

Souvenirs and handicrafts of a destination arevery important to most of travellers and tourists through their travel experience. As they always keen on having a tangible object to take home, which represents the places they have visited, the sightseeing they have seen, and the memories they have made.Since tourism is considered a complex industry, which consists of numerous services, facilities, and activities with a lot of intangible items that forms the whole tourist experience, the souvenir is the only tangible item that can be retained from this visited destination.Therefore, it is crucial to maintain a satisfying service at the souvenir and handicraft sector, to achieve tourists' satisfactionat the destination. The objective of this research is to determine to what extent does buying souvenirs and handicrafts affects the tourists' overall satisfaction. Questionnaires were distributed on a random sample of tourists at Luxor city. The overall findings refer to the importance of visiting destination's bazars and its effect on tourists' overall satisfaction to get a souvenir that reminds them with the destination.Results have revealed that there is a positive and significant relationship between bazars' staff treatment, scamming, crowd, product variety and hassle with tourist's' satisfaction.

Key words: Souvenir - Handcrafts - Satisfaction - Hand-madeBazars. 
- The role of souvenirs and handicrafts in achieving tourists' satisfaction "Applied on Luxor city"

\section{دور العاديات و السلع السياحية فى تهقيق رضاء السائح بالتطبيق على هدينة الأقصر}

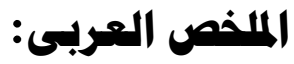

تهثل الهدايا التذكارية والحرف اليدوية للهقصد السياحي أهمية كبيرة لمعظم المسافرين والسائحين، فهم يحرصون دائمًا على الحصول على شيء ملموس يهكن العودة بـه إلى بلادهم يهثل الأماكن التي قاموا بزيارتها،المعالم السياحية التي ثاهدوها، وكذلك الذكريات التي دائما تذكرهم بهذا المقصد. ونظرًا لأن السياحة تعتبر صناعة معقدة، تتكون من العديد من الخدمات والمرافق والأنشطة و الكثير من العناصر غير الملموسة و التي تشكل التجربـة السياحية، إلا أن التذكارات السياحىلة هى التى تعتبر العنصر الوحيد الملموس الذي يهكن الاحتفاظ به من زيارة هذا المقصد. ولهذا فيجب الحفاظ على تقديه خلمـة مرضية بقطاع الهدايا التذكارية والحرف اليدوية لتحقيق رضاء السـائحين وضهـان تكرار الزيارة. تهدف هذه الدراسـة إلى تحديد مدى تأثير عملية شراء الهدايا التذكاريـة والحرف اليدوية على رضـاء السـائحين ومن ثم فقد تم توزيـع استتمارات استقصاء على عينـة عشوائية من السـائحين مِ مدينة الأقصر. تشير النتائج الإجمالية لهذه الدراسة إلى أهمية زيارة محلات العاديات و السلع السياحية بالمقصد السياحي كجزء هام من البرنامج السياحى وتأثير ذلك على مستوى الرضاء العام للسائحين فى الحصول على هدايا تذكارية تذكرهم بهذا المقصد. كشفت النتائج إلى أن هنالك علاقة إيجابية وارتباط بين معاملة موظفي محلات السلع و العاديات السياحية ، الاحتيال و الغش، الزحام، تنوع المنتجات والمشاحنات والمضايقات على رضاء السائحين.

الكلمات الدالة :

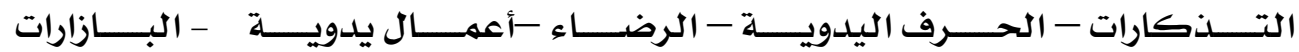




\section{Introduction:}

The word "souvenir" is of a French origin, indicating the action of remembering. Accordingly, a souvenir is a small artistically crafted object, which serves as a memento (Marangkun, W.and Thipjumnong,A., 2018). It is represented by an object through which something is remembered, whether a place, people, situation,.....etc. (Swanson,K., and Timothy,D., 2012). Gordon (1986 P.135) defines them as arts and handicrafts that reflect the culture and locality of the destination. Swanson and Timothy (2012) stated that some researchers describe them as having the ability to capture, recollect, and prove an extraordinary or sacred time or space. Thus, they use these souvenirs in sharing their experience and enhancing it.Shtudiner et al. (2019) defined them as tools which are important for transformation in which can reconnect travelers to feelings, thoughts and several experiences that is related to the destination they have visited.

Souvenirs are ancient as they have been related to travelling. Since people have started to travel and visit different places, they get used to bring back memorable and tangible objects from their journeys in the form of souvenirs or handicrafts (Paraskevaidis, P., and Andriotis, K., 2015),(Trinh, T.et al. 2014). Morgan and Pritchard (2005) mentioned that this memento will always remind the tourists of places, people, sites, traditions, and the whole intangible travel and tourism experience. Singh (2017) described souvenirs as something which have emotional value, symbolizes a relation between people, moments, feelings, locations or situations and something which can evoke memories.

Before tourists decide to purchase a souvenir, they consider the related attributes of the product, which refers to the value expected, needed, and desired. If there is matching between souvenirs' value and the desired attributes, therefore tourists will 
- The role of souvenirs and handicrafts in achieving tourists' satisfaction

"Applied on Luxor city"

be satisfied. (Beigpoor, R., 2012). Thus, the word satisfaction is referred to a post purchasing feeling or attitude towards a product (Corte et al. 2015).

The objective of this research is to determine to what extent does buying souvenirs and handicrafts affects the tourists' overall satisfaction at the destination.

\section{Literature Review:}

Souvenirs' importance:

Cohn (1995) clarified that tourism and buying souvenirs are correlative activities. As buying souvenirs have great importance and several benefitson theeconomy, society, culture, and environment. These benefits include both the host community (destination), as well as the tourist. Both of them reflect the demand and supply dimensions of souvenirs.Dogooc (2017) summarized the role of souvenirs for the destination from the supply side which includes: creating employment, highlighting competitive advantages, increasing revenues, performing as indirect marketing, preserving identity and cultural characteristics, and finally preserving ancient crafts industries for future generations which all related to sustainability. As for the demand side which is represented by tourists, PenerLiev (2012) stated that souvenirs helps in having a tangible reminder of an enjoyable time, an extraordinary experience of meeting people, customs, traditions, places, and store memories related to travel.

One more important role was added by Dumbrovska and Fialova(2019)in which souvenirs contribute in preserving and establishing the destination's image as tourists can give them as gifts to their family and friends or can use them as an indicator of visiting this destination. Therefore, they act as a promotion tool for this destination and contribute in raising its attractiveness, history, sightseeings and maintaining its image.

Regarding the economic importance of souvenirs, from ancient times Kim and Littrell (1999)reported that Philippines 
has a good example for representing the importance of the souvenir industry, as more than $80 \%$ of tourists' spending-after paying the tourist package-is on buying souvenirs.It earns only from selling souvenirs more than $\$ 30$ million a year. Moreover, Americans spend from $33 \%$ to $56 \%$ of their travel budget on buying souvenirs.A study by Wong, J. and Law, R. (2003) reported that shopping during travelling accounts for half of all travel expenditures. Magindol and Hassand (2014) also reported that tourism shopping receipts counted for one fourth of the total tourism receipts in Malaysia in 2007. Recent studies stated that tourists spent about one third of their tourism expenditure on shopping (Roostika, R. et al. 2015).

According to Swanson (2004), the sales' volume on souvenirs affirm their economic importance as in 1990, the United States stated that there is 20 billion dollars spent yearly on buying souvenirs. Furthermore, in the beginning of 1990 Germany declared that around 1 to 1.5 billion dollars also were spend on the same issue while in 2004, Switzerland were 67 million Swiss Franc were spent on souvenirs' purchasing. As for Chinese leisure travelers, buying souvenirs was accounted as the most important purchases ever made (Cai, L. et al. 2001).Another study stated that souvenirs are important to retailers as well as the destination as it contributes in destination's economic growth (Amaro et al. 2019).

Souvenirs according to (Zhao, 2018) are important as they are considered as a tool for measuring culture, economy, politics and folklore and also theyare the yardstick for the development of the social civilization. Its value increased by increasing its cultural characteristics.

\section{Souvenir Types and Preferences:}

Tourists tend to purchase souvenirs either for themselves, or as a gift for family and friends. These souvenirs may include variety of either hand-made or mass produced items. These mass 
- The role of souvenirs and handicrafts in achieving tourists' satisfaction

"Applied on Luxor city"

produced items are represented in local crafts, postcards, fine arts, accessories, jewelry, and clothes (Swanson,K.,2004). Sthapit (2018) added more items to the mass produced ones that are produced in huge amounts and are not unique or authenticsuch as: branded hats with logo and name of the destination present, antiques, paintings and photographs, key rings, t- shirts, mugs, and fridge magnets. According to Moscardo, G. (2004), travelers with urban entertainment desires tend to buy such souvenirs which display the logo of the visited places.

Handmade souvenirs reflect the uniqueness and authenticity of products and they are presented in ethnic souvenirs, which are created by local citizens to represent traditions, religion, arts, architecture.....etc (Smith,H., 1987). According to Moscardo, G. (2004), travelers who are interested in ethnic, arts, local citizens, culture of the destination are attracted to buy local arts and handicrafts. On the otherhand, travelers who are interested in history and nature activities are attracted to buy also local arts and handicrafts as well as printed materials which represent the history and nature sites that have been visited. Another study of Schluter, R. (1998) reported that ethnic tourists; who are not able to retrieve the local society with its traditions, buy ethnic souvenirsinstead, to help them to live again with the trip or the moments they have experienced in the destination. She also added that tourists who prefer haunting and collection will seek out souvenirs of archeological or nature based features such as rocks and stuffed animals.

Littrell et al. (1993) mentioned that tourists' preferences in buying souvenirs can also vary according to gender and nationality for example women tend to purchase souvenirs more frequently than men. Wilkins, H. (2010) reported that men are most likely to purchase discounted and branded products while women tend to buy products which are related more to destination. Regardingnationality, Penerliev, M. (2012) clarified 
that Russians and Greek tend to bargain for the price of items bought while Jews tend to buy the cheapest goods. Americans prefer hand-made items and are willing to spendmuch amount of money on them. Dutch and Germans tend to buy practical items while Scandinavians tend to buy things that will be useful for their everyday life. As for Italians and Spaniards they tend to buy small souvenirs in large quantities as gifts for family and friends. Finally, French tourists tend to buy local products which reflect the destinations authenticity.

According to Goo, Y. and Shen, M. (2011), souvenirs can be classified into 5 main categories. First category is the tangible items that remind the tourist of his travel experience such as: pictorial images which include postcards, posters, photographs, illustrated books, and pictures. Singh (2018) stated that thesecond category is represented in natural souvenirs which are also known as piece of a rock, this type includes rocks, shells, pinecones, driftwood, leather goods, stuffed alligators......etc. He also added the symbolic souvenirs which are also known as antiques, this category includes replicas of well- known attractions, and miniaturized samples.Marwick, M.C (2001) and Singh (2018) stated that the fourth category stands for markers which are represented in mugs, coasters, t-shirts, caps, neckties, ashtrays and key rings, ...etc and all of which hasn't unique design but they are marked with destination's logos. This fourth category reflects the mass produced souvenirs. Finally the fifth category according to Gordon (1986) includes objects such as: food, clothing, handicrafts and utensils ...etc which reflects traditions, local culture, and heritage within the destination.

\section{Souvenir Value:}

Buying souvenirs play a major role in tourists' travel experience and memory thus; tourists take buying decisions based on the value of the product which plays an essential role in affecting these decisions. These values are classified as follows: 
The role of souvenirs and handicrafts in achieving tourists' satisfaction
"Applied on Luxor city"

- Use Value: Thompson et al. (2012) mentioned that souvenir's value lies in its usage thus, tourists can use it as a memorial or a reminder for his tourism experience so as he can use it every day during his trip and after returning back home.

- Exchange Value:refers to souvenirs that its value will be increasedby time. They might be purchased either for their prices versus value or for investment purposes (Wei, W., 2018)

- Sign Value: this kind is attached to prestigious purposes, social status, and personal identity. They are usually authentic, unique, luxurious souvenirs. (Gasana,P.,2009).

- Spiritual Value: this could be seen in religious souvenirs or souvenirs that are attached to spiritual beliefs (Swanson,K.and Timothy,D., 2012).

\section{Souvenirs and satisfaction attributes:}

Durie and Kebede (2017) stated that tourist satisfaction is considered the main essential objective in travel experience where as loyalty towards product/ destination is increased by satisfied tourists and therefore repurchase the product/service once again. Thus, satisfaction with travel experiences contributes in destination loyalty so as loyalty degree depends on the level of satisfaction that is reflected in the intention of re-visiting the destination and recommending it to others. Amaro et al. (2019) added that tourists' overall satisfaction with a visited destination has been influenced by retail and souvenirs shops thus, satisfied tourist with souvenir shopping contributes in their loyalty towards the destination.

According to Corte and Sciarelli (2015) tourist's satisfaction can be measured through the relation between tourist perspectives, expectations, features, and value gained.Attributes of souvenirs that contribute in tourists' satisfaction may include: authenticity, relation to citizens, portability, usability, price value, and culture relation (Goeldner, R. et al. 2000). Other attributes might include:design criteria, superior quality, 
workmanship, attractive colors, traditional themes, nature-based, symbolism of visited places, and functional qualities of the product (OLaLcre,F,E., 2017). Other studies mentioned that there are four factors that affect tourist's shopping satisfaction; which are:

- Product/service tangible quality: this includes physical factors of the product and store such as: accessibility, lighting, view display, neatness, and cleanliness(Abrudan, I.N. and Dabija,D., 2014).

- Staff service quality: this includes features and characteristics of personnel and sellers such as: language skills, honesty, knowledge, attitudes, and helpfulness (Barutcu, S. et al. 2011), (Wong, I.A. and Wan Y,K., 2013)and (Khairannisa, H., et al. 2016)

- Product/ service value: this is mainly concerned with the price of the product or service regarding its value, or benefit. This also includes the presence of price tags displayed on products, and various payment methods services. (Heung, V. and Cheng,E., 2000) and it is called also Display attribute ((Suhartanto, D., 2016)

-Product reliability: this is shown through the diversity of products/services offered and presented as well as the continued and ongoing usefulness and benefits. (Lehew, M. and Wesley,S., 2007) and(Heung,V., and Cheng,E., 2000).

Dissatisfaction elements might include: the lack of portability, undeclared prices, low quality, store location, reputation, usability, personnel expertise, unfriendly dealing, authenticity, variety, safety, and cleanliness (Anuar, A. and Haron, N., 2017) and (Marangkun, W. and Thipjumnong, A., 2018). The study of (Goo, Y., and Shen, M., 2011) clarified that one of the most disturbing situations that causes dissatisfactionis when buying a souvenir as a memento of tourism experience thenit is discovered to be neither authentic nor genuine as 
The role of souvenirs and handicrafts in achieving tourists' satisfaction

"Applied on Luxor city"

imagined and expected. This happens when it is written on it another country, not the country of origin (COC) because it is manufactured in other countries due to economic reasons. This happens only on mass produced products that are marked with destination's logo. Thus, it causes negative effect and dissatisfaction of tourists regarding souvenirs and handicrafts and consequently reflected on his overall feeling towards his travel experience and the destination as a whole.

\section{Methodology:}

Questionnaires were distributed among random sample of tourists at Luxor city. They are used as a tool for data collection to determine the factors affecting tourists' satisfaction regarding souvenirs and handcrafts. The questionnairewas divided into two parts. First part is related to the personal data which includes gender, age, and nationality. Second part is related to the process of buying the souvenirs and handcrafts from the bazars and this part includes Likert Scale with its associated values from (1 strongly agree to 5 strongly disagree). This scale is used to determine the significant differences and also to indicate the level of agreement and disagreement for the statements that show tourists' satisfaction towards the procedure of buying the souvenirs and handcrafts in Luxor city.Thisin turn will reflect their overall satisfaction and consequently revisiting the destination.Questionnaire also measures some souvenirs' attributes that in turn lead to tourists' satisfaction. It measures the tangible quality by asking about the accessibility of bazars and the display format of souvenirs. It also measures the staff service quality by asking about the personnel and sellers' treatment and whether they were helpful and friendly. Regarding the value, tourists have been asked about the display of price tags on souvenirs in addition to the reliability by asking about the diversity of the souvenirs present. 


\section{Sampling:}

The objective of this research is to know the role of buying souvenirs and handcrafts from Luxor city in achieving tourists' satisfaction. Thus, questionnaires were distributed among random sample of tourists. It is conducted from January to May 2019. The completed questionnaires were(384)ones from total (400), distributed randomly among different nationalities. These nationalities were represented as follows: Spanish 43\%, Chinese $12.8 \%$, German $11.2 \%$, Americans 9.4\%, British 8.6\%, Russian $6.3 \%$, Mexicans $5.7 \%$ and finally Swiss were $3.1 \%$.

\section{Data Analysis:}

The statistical tool exploited in this research is the quantitative method analyzed by SPSS program version 24 . Cronbach's Alpha is used to assess the reliability of the questions. Pearson Correlation is used to determine the correlation between research dimensions and tourists' satisfaction. Regression equations were also applied to know the dimensions that influence tourists' satisfaction.

\section{Results and Discussion:}

\section{First: Reliability Analysis}

\section{Table (1): Measuring reliability degree for the questionnaires}

\begin{tabular}{|l|l|}
\hline Questions & Alpha Cronbach's \\
\hline 25 & 0.741 \\
\hline
\end{tabular}

As depicted in table (1), the Cronbach's Alpha reliability was computed for 25 questions and the tests showed that the reliability coefficients for all questions were above .741 which indicates that the instrument is reliable for being used. Second: Descriptive Analysis

Table (2): Demographic Data of Respondents. 
- The role of souvenirs and handicrafts in achieving tourists' satisfaction "Applied on Luxor city"

\begin{tabular}{|c|c|c|c|c|}
\hline \multirow{2}{*}{$\begin{array}{l}\text { Demographi } \\
\text { c Data }\end{array}$} & \multirow{2}{*}{ Attribute } & \multicolumn{2}{|c|}{ Statistics } & \multirow[t]{2}{*}{ Rank } \\
\hline & & Freq. & $\%$ & \\
\hline \multirow{2}{*}{ Gender } & Female & 246 & $64.1 \%$ & 1 \\
\hline & Male & 138 & $35.9 \%$ & 2 \\
\hline \multicolumn{2}{|l|}{ Total } & 384 & \multicolumn{2}{|l|}{$100 \%$} \\
\hline \multirow{4}{*}{ Age } & From 41-60 years & 256 & $66.7 \%$ & 1 \\
\hline & More than 60 years & 69 & $18 \%$ & 2 \\
\hline & From $20-40$ years & 59 & $15.4 \%$ & 3 \\
\hline & Less than 20 years & 0 & 0 & 4 \\
\hline \multicolumn{2}{|l|}{ Total } & 384 & \multicolumn{2}{|l|}{$100 \%$} \\
\hline \multirow{8}{*}{ Nationality } & Spanish & 165 & $43.0 \%$ & 1 \\
\hline & Chinese & 49 & $12.8 \%$ & 2 \\
\hline & German & 43 & $11.2 \%$ & 3 \\
\hline & American & 36 & $9.4 \%$ & 4 \\
\hline & British & 33 & $8.6 \%$ & 5 \\
\hline & Russian & 24 & $6.3 \%$ & 6 \\
\hline & Mexican & 22 & $5.7 \%$ & 7 \\
\hline & Swiss & 12 & $3.1 \%$ & 8 \\
\hline \multicolumn{2}{|l|}{ Total } & 384 & \multicolumn{2}{|l|}{$100 \%$} \\
\hline
\end{tabular}




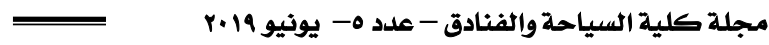

Table (2) indicated that $64.1 \%$ of the respondents were female, and $35.9 \%$ were male. Regarding the age of respondents, $66.7 \%$ of the respondents were between $41-60$ years, followed by tourists who were more than 60 years by $18 \%$, then who were between $20-40$ years by $15.4 \%$, and finally, who were Less than 20 years by $0 \%$. Respondents' nationality varied between German11.2\%, British8.6\%, Mexican5.7\%, Chinese12.8\%, Swiss 3.1\%, Russian 6.3\%, American 9.4\% and Spanish $43.0 \%$.

Table (3): Keen to know about souvenirs and handcrafts distinguishing the destination before purchasing

\begin{tabular}{|l|l|l|l|l|}
\hline Factor & Variables & Frequency & $\begin{array}{l}\text { Percentage } \\
(\%)\end{array}$ & Rank \\
\hline $\begin{array}{l}\text { Are you always } \\
\text { keen to know } \\
\text { about } \\
\text { souvenirs and } \\
\text { handcrafts } \\
\text { distinguishing } \\
\text { the destination } \\
\text { before } \\
\text { purchasing? }\end{array}$ & Yes & 269 & $70.1 \%$ & 1 \\
\hline Total & 115 & $29.9 \%$ & 2 \\
\hline
\end{tabular}

The results state clearly $70.1 \%$ from research sample always keen to know about souvenirs and handcrafts distinguishing the destination before purchasing but the rest of the research sample by $29.9 \%$ don't matter with them this issue.

Table (4):Preferences of buying souvenirs and handcrafts from famous places

\begin{tabular}{|l|l|l|l|l|}
\hline & Variables & Frequency & Percentage & Rank \\
\hline
\end{tabular}




The role of souvenirs and handicrafts in achieving tourists' satisfaction
\begin{tabular}{|l|l|l|l|l|}
\hline \multirow{2}{*}{ "Applied on Luxor city" } & & & \\
\hline & & & $(\%)$ & \\
\hline $\begin{array}{l}\text { Doctor you prefer } \\
\text { to buy } \\
\text { souvenirs and } \\
\text { handcrafts } \\
\text { from famous } \\
\text { places? }\end{array}$ & Yes & 205 & $53.4 \%$ & 1 \\
\cline { 2 - 5 } & No & 179 & $46.6 \%$ & 2 \\
\hline Total & & 384 & $100 \%$ & - \\
\hline
\end{tabular}

The results state clearly that the majority of respondents $53.4 \%$ prefer to buy souvenirs and handcrafts from famous places, meanwhile $46.6 \%$ don't prefer that.

Table (5) Time of buying souvenirs and handcrafts during the trip

\begin{tabular}{|c|c|c|c|c|}
\hline Factor & Variables & $\begin{array}{l}\text { Frequenc } \\
\mathbf{y}\end{array}$ & $\begin{array}{l}\text { Percentag } \\
\text { e }(\%)\end{array}$ & $\begin{array}{l}\text { Ran } \\
\mathbf{k}\end{array}$ \\
\hline \multirow{4}{*}{$\begin{array}{l}\text { When did } \\
\text { you buy } \\
\text { souvenirs } \\
\text { and } \\
\text { handcrafts } \\
\text { within } \\
\text { your trip? }\end{array}$} & Any Time & 270 & $70.3 \%$ & 1 \\
\hline & $\begin{array}{l}\text { At the end of } \\
\text { the trip }\end{array}$ & 84 & $21.9 \%$ & 2 \\
\hline & $\begin{array}{l}\text { In the middle of } \\
\text { the trip }\end{array}$ & 30 & $7.8 \%$ & 3 \\
\hline & $\begin{array}{l}\text { At the } \\
\text { beginning of } \\
\text { the trip }\end{array}$ & 0 & 0 & 4 \\
\hline \multicolumn{2}{|l|}{ Total } & 384 & $100 \%$ & - \\
\hline
\end{tabular}

The results state clearly that the answer (Any time) is the highest number for respondents by $70.3 \%$. (At the end of the trip) is the second $21.9 \%$. (In the middle of the trip) ranks the third by $7.8 \%$. Finally $0.0 \%$ is for the beginning of the trip which indicates that is no one thinks about buying any souvenirs upon his arrival. 
مجلة كلية السياحة والفنادق - عدد ه- يونيو 19.r

Table (6): The most favorable kind of souvenirs and handcrafts that you prefer to buy from Luxor*

\begin{tabular}{|c|c|c|c|c|}
\hline Factor & Variables & $\begin{array}{l}\text { Frequenc } \\
\mathbf{y}\end{array}$ & $\begin{array}{l}\text { Percenta } \\
\text { ge }(\%)\end{array}$ & $\begin{array}{l}\text { Ran } \\
\mathbf{k}\end{array}$ \\
\hline \multirow{13}{*}{$\begin{array}{l}\text { What are } \\
\text { the most } \\
\text { favorable } \\
\text { kinds of } \\
\text { souvenirs } \\
\text { and } \\
\text { handcrafts } \\
\text { that you } \\
\text { prefer to } \\
\text { buy from } \\
\text { Luxor? }\end{array}$} & $\begin{array}{l}\text { Cotton and } \\
\text { Clothes }\end{array}$ & 194 & $50.5 \%$ & 1 \\
\hline & Papyrus & 113 & $29.4 \%$ & 2 \\
\hline & Perfumes & 88 & $22.8 \%$ & 3 \\
\hline & Gold and Silver & 62 & $16.1 \%$ & 4 \\
\hline & \multicolumn{4}{|l|}{ Others (78) } \\
\hline & $\begin{array}{l}\text { Pharaonic } \\
\text { Sculptures }\end{array}$ & 17 & $4.4 \%$ & 5 \\
\hline & $\begin{array}{l}\text { Fairtrade made } \\
\text { by hand } \\
\text { handcrafts }\end{array}$ & 13 & $3.4 \%$ & 6 \\
\hline & Books & 12 & $3.1 \%$ & 7 \\
\hline & $\begin{array}{l}\text { Archaeological } \\
\text { reproductions }\end{array}$ & 11 & $2.9 \%$ & 8 \\
\hline & $\begin{array}{l}\text { Small } \\
\text { Sculptures }\end{array}$ & 9 & $2.3 \%$ & 9 \\
\hline & Art Replicas & 7 & $1.8 \%$ & 10 \\
\hline & Carpet & 5 & $1.3 \%$ & 11 \\
\hline & Figures & 4 & $1 \%$ & 12 \\
\hline \multicolumn{2}{|l|}{ Total } & 535 & $139 \%$ & - \\
\hline
\end{tabular}

*Respondents have chosen more than one answer

As seen above in table (6), cotton and clothes are the most favorable kind of souvenirs that tourist prefer to buy from Luxor with $50.5 \%$. This is followed by papyrus (29.4\%), then perfumes (22.8\%) and lastly gold and silver (16.1\%).Respondents also have mentionedother products to buy which are in order as follows:pharonic Sculptures, fairtrade made by hand handcrafts, 
The role of souvenirs and handicrafts in achieving tourists' satisfaction

"Applied on Luxor city"

books, archeological reproductions, small sculptures, art replicas, carpets, and figures.

Table (7):Accompanied person to go with when shopping souvenirs and handicrafts

\begin{tabular}{|c|c|c|c|c|}
\hline Factor & Variables & Frequency & $\begin{array}{l}\text { Percentage } \\
(\%)\end{array}$ & Rank \\
\hline \multirow{4}{*}{$\begin{array}{l}\text { In } \\
\text { accompany } \\
\text { with whom } \\
\text { do you prefer } \\
\text { more to go } \\
\text { shopping } \\
\text { souvenirs } \\
\text { and } \\
\text { handicrafts? }\end{array}$} & Friends & 169 & $44.0 \%$ & 1 \\
\hline & Tour Guide & 111 & $28.9 \%$ & 2 \\
\hline & Alone & 100 & $26.0 \%$ & 3 \\
\hline & $\begin{array}{l}\text { Tour } \\
\text { Leader }\end{array}$ & 4 & $1.0 \%$ & 4 \\
\hline \multicolumn{2}{|l|}{ Total } & 384 & $100 \%$ & - \\
\hline
\end{tabular}

Table (7) indicated that $44.0 \%$ of the respondents have prefered more to go shopping souvenirs and handicraftswithfriends, tour guide by $28.9 \%$, and going alone by $26.0 \%$ then finally withtheir tour leader by $1.0 \%$. 
Table (8): Buying souvenirs and handcrafts

\begin{tabular}{|c|c|c|c|c|c|c|c|c|}
\hline Factor & 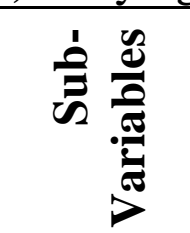 & $\dot{\vec{d}}$ & ¿ & 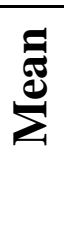 & 官 & 폴 & 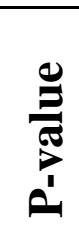 & $\mathbf{R}$ \\
\hline \multirow{5}{*}{$\begin{array}{c}\text { Buying } \\
\text { souvenirs } \\
\text { and } \\
\text { handcrafts } \\
\text { represent a } \\
\text { great } \\
\text { priority as a } \\
\text { part of your } \\
\text { trip. }\end{array}$} & $\begin{array}{l}\text { Strongly } \\
\text { disagree }\end{array}$ & $\infty$ & $\tilde{\nabla}$ & \multirow[t]{5}{*}{ חั? } & \multirow[t]{5}{*}{$\stackrel{0}{\infty}$} & \multirow{5}{*}{ 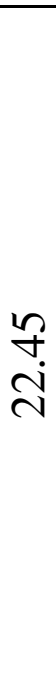 } & \multirow{5}{*}{ 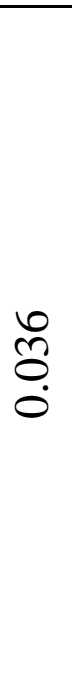 } & \multirow[t]{5}{*}{12} \\
\hline & Disagree & $\infty$ & $\stackrel{0}{\sim}$ & & & & & \\
\hline & Neutral & $\bar{\beth}$ & $\frac{n}{m}$ & & & & & \\
\hline & Agree & 8 & $\stackrel{+}{\sim}$ & & & & & \\
\hline & $\begin{array}{c}\text { Strongly } \\
\text { agree }\end{array}$ & 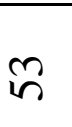 & $\stackrel{\infty}{\stackrel{\infty}{\sim}}$ & & & & & \\
\hline \multirow{4}{*}{$\begin{array}{c}\text { There is a } \\
\text { distinguishe } \\
\text { d variety of } \\
\text { souvenirs } \\
\text { and } \\
\text { handicrafts } \\
\text { at Luxor } \\
\text { Bazars that } \\
\text { fit your }\end{array}$} & $\begin{array}{l}\text { Strongly } \\
\text { disagree }\end{array}$ & 0 & 0 & \multirow[t]{3}{*}{$\frac{0}{r}$} & \multirow[t]{3}{*}{$\stackrel{\infty}{\infty}$} & \multirow{4}{*}{ 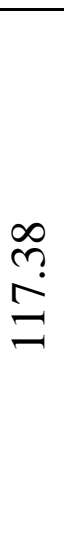 } & \multirow{4}{*}{$\begin{array}{l}8 \\
8 \\
8\end{array}$} & \multirow[t]{4}{*}{6} \\
\hline & Disagree & 工 & $\underset{\forall}{\forall}$ & & & & & \\
\hline & Neutral & $\stackrel{\curvearrowleft}{\sim}$ & $\begin{array}{l}0 \\
\text { m }\end{array}$ & & & & & \\
\hline & Agree & $\hat{\Sigma}$ & ॄே & & & & & \\
\hline
\end{tabular}




\begin{tabular}{|c|c|c|c|c|c|c|c|c|}
\hline $\begin{array}{l}\text { needs and } \\
\text { desires. }\end{array}$ & $\begin{array}{l}\text { Strongly } \\
\text { agree }\end{array}$ & 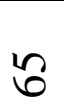 & 0 & & & & & \\
\hline & & & & & & & & \\
\hline \multirow{5}{*}{$\begin{array}{c}\text { Souvenirs } \\
\text { and } \\
\text { handcrafts } \\
\text { that reflect } \\
\text { destination's } \\
\text { cultural } \\
\text { heritage are } \\
\text { the most } \\
\text { attractive } \\
\text { for you. }\end{array}$} & $\begin{array}{l}\text { Strongly } \\
\text { disagree }\end{array}$ & 0 & 0 & \multirow[t]{5}{*}{$\stackrel{n}{7}$} & \multirow[t]{5}{*}{ 成 } & \multirow{5}{*}{$\begin{array}{l}\stackrel{a}{a} \\
\stackrel{2}{\Delta}\end{array}$} & \multirow{5}{*}{$\begin{array}{l}8 \\
8 \\
0\end{array}$} & \multirow[t]{5}{*}{2} \\
\hline & Disagree & 0 & $\stackrel{0}{\longrightarrow}$ & & & & & \\
\hline & Neutral & $n$ & 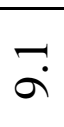 & & & & & \\
\hline & Agree & ఠి & กี & & & & & \\
\hline & $\begin{array}{c}\text { Strongly } \\
\text { agree }\end{array}$ & $\stackrel{\mathscr{g}}{ \pm}$ & $\frac{N}{n}$ & & & & & \\
\hline & & & & & & & & \\
\hline \multirow{5}{*}{$\begin{array}{c}\text { You are } \\
\text { always keen } \\
\text { to buy } \\
\text { souvenirs } \\
\text { and } \\
\text { handcrafts } \\
\text { that remind } \\
\text { you of the } \\
\text { destination. }\end{array}$} & $\begin{array}{l}\text { Strongly } \\
\text { disagree }\end{array}$ & 6 & $\stackrel{0}{-}$ & \multirow[t]{5}{*}{$\stackrel{7}{+}$} & \multirow[t]{5}{*}{$\stackrel{n}{\infty}$} & \multirow{5}{*}{$\begin{array}{l}\infty \\
\text { å } \\
\text { a }\end{array}$} & \multirow{5}{*}{$\begin{array}{l}8 \\
8 \\
0\end{array}$} & \multirow[t]{5}{*}{1} \\
\hline & Disagree & $\simeq$ & $\vec{m}$ & & & & & \\
\hline & Neutral & ñ & n? & & & & & \\
\hline & Agree & $\stackrel{2}{2}$ & $\stackrel{\infty}{\stackrel{\infty}{\forall}}$ & & & & & \\
\hline & $\begin{array}{c}\text { Strongly } \\
\text { agree }\end{array}$ & $\underline{6}$ & 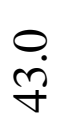 & & & & & \\
\hline $\begin{array}{l}\text { Prices of } \\
\text { souvenirs }\end{array}$ & $\begin{array}{l}\text { Strongly } \\
\text { disagree }\end{array}$ & 0 & 0 & ণิ & $\stackrel{2}{n}$ & $\dot{0}$ & 8.0 & 3 \\
\hline
\end{tabular}




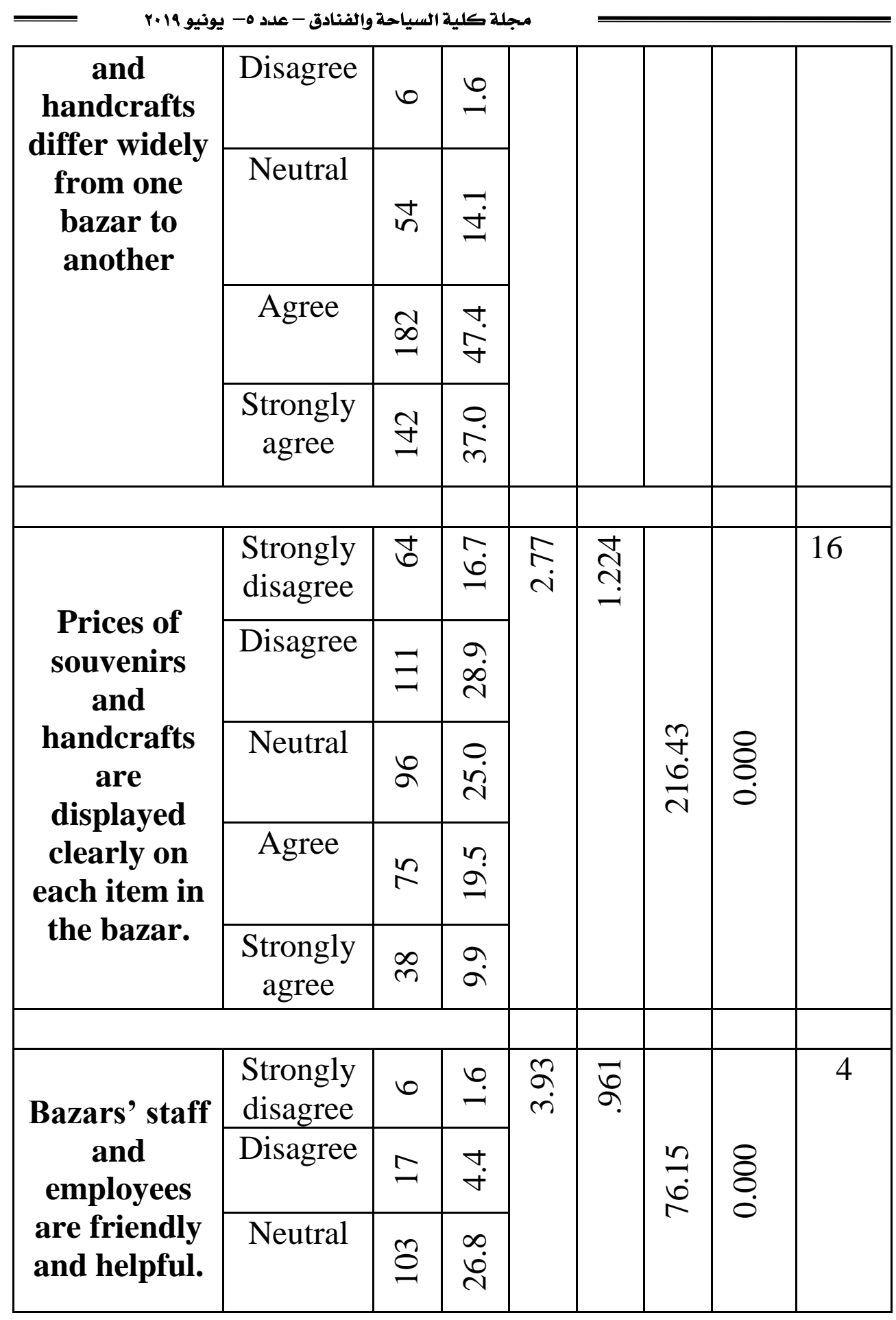




\begin{tabular}{|c|c|c|c|c|c|c|c|c|}
\hline \multicolumn{9}{|c|}{$\begin{array}{c}=\text { The role of souvenirs and handicrafts in achieving tourists' satisfaction } \\
\text { "Applied on Luxor city" }\end{array}$} \\
\hline & Agree & $\stackrel{\infty}{\simeq}$ & $\ddot{m}$ & & & & & \\
\hline & $\begin{array}{c}\text { Strongly } \\
\text { agree }\end{array}$ & 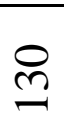 & $\ddot{m}$ & & & & & \\
\hline & & & & & & & & \\
\hline \multirow{5}{*}{$\begin{array}{l}\text { You have } \\
\text { suffered } \\
\text { from } \\
\text { crowdness } \\
\text { during } \\
\text { buying } \\
\text { souvenirs } \\
\text { and } \\
\text { handcrafts }\end{array}$} & $\begin{array}{l}\text { Strongly } \\
\text { disagree }\end{array}$ & 0 & 0 & \multirow[t]{5}{*}{ nn } & \multirow[t]{5}{*}{$\begin{array}{l}\infty \\
\infty \\
\infty\end{array}$} & \multirow{5}{*}{$\hat{n}$} & \multirow{5}{*}{$\begin{array}{l}\text { ஸै } \\
0 \\
0\end{array}$} & \multirow[t]{5}{*}{9} \\
\hline & Disagree & $\stackrel{\wp}{\forall}$ & Е & & & & & \\
\hline & Neutral & $\stackrel{?}{\Xi}$ & $\frac{n}{n}$ & & & & & \\
\hline & Agree & $\stackrel{+}{n}$ & $\stackrel{9}{\dot{+}}$ & & & & & \\
\hline & $\begin{array}{c}\text { Strongly } \\
\text { agree }\end{array}$ & ชู & 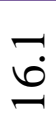 & & & & & \\
\hline & & & & & & & \multirow{6}{*}{$\begin{array}{l}8 \\
8 \\
0\end{array}$} & \\
\hline \multirow{5}{*}{$\begin{array}{c}\text { You have } \\
\text { suffered } \\
\text { from } \\
\text { different } \\
\text { ways of } \\
\text { hassle } \\
\text { forcing you } \\
\text { to buy } \\
\text { souvenirs } \\
\text { and } \\
\text { handcrafts } \\
\text { at bazars. }\end{array}$} & $\begin{array}{l}\text { Strongly } \\
\text { disagree }\end{array}$ & $=$ & ก) & \multirow[t]{5}{*}{$\stackrel{n}{\stackrel{n}{r}}$} & \multirow[t]{5}{*}{ 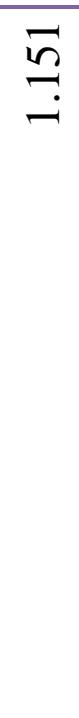 } & \multirow{5}{*}{$\stackrel{n}{n}$} & & \multirow[t]{5}{*}{11} \\
\hline & Disagree & 9 & $\stackrel{0}{0}$ & & & & & \\
\hline & Neutral & $\stackrel{m}{=}$ & $\stackrel{+}{\text { ণे }}$ & & & & & \\
\hline & Agree & $\infty$ & กิ & & & & & \\
\hline & $\begin{array}{c}\text { Strongly } \\
\text { agree }\end{array}$ & a & $\stackrel{n}{+}$ & & & & & \\
\hline
\end{tabular}




\begin{tabular}{|c|c|c|c|c|c|c|c|c|}
\hline \multirow{5}{*}{$\begin{array}{c}\text { You have } \\
\text { been } \\
\text { scammed } \\
\text { during } \\
\text { buying } \\
\text { souvenirs } \\
\text { and } \\
\text { handcrafts. }\end{array}$} & $\begin{array}{l}\text { Strongly } \\
\text { disagree }\end{array}$ & $=$ & $\hat{i}$ & \multirow[t]{5}{*}{$\tilde{\sigma}$} & \multirow[t]{5}{*}{$\underset{8}{8}$} & \multirow{5}{*}{ 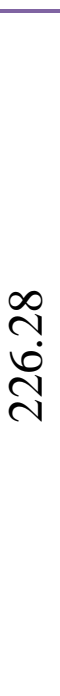 } & \multirow{5}{*}{ ஜ } & \multirow[t]{5}{*}{14} \\
\hline & Disagree & $\stackrel{さ}{\beth}$ & $\frac{m}{m}$ & & & & & \\
\hline & Neutral & $\stackrel{ \pm}{\longrightarrow}$ & $\dot{q}$ & & & & & \\
\hline & Agree & क & $\stackrel{\vec{\lambda}}{\vec{\lambda}}$ & & & & & \\
\hline & $\begin{array}{c}\text { Strongly } \\
\text { agree }\end{array}$ & $\ddot{n}$ & $\ddot{a}$ & & & & & \\
\hline \multirow{6}{*}{$\begin{array}{c}\text { Scam } \\
\text { exposure } \\
\text { affects } \\
\text { negatively } \\
\text { your trip. }\end{array}$} & & & & & & & & \\
\hline & $\begin{array}{l}\text { Strongly } \\
\text { disagree }\end{array}$ & $\simeq$ & $\vec{m}$ & \multirow[t]{5}{*}{$\begin{array}{l}b \\
\dot{n}\end{array}$} & \multirow[t]{5}{*}{$\stackrel{n}{m}$} & \multirow{5}{*}{$\frac{9}{\infty}$} & \multirow{5}{*}{$\begin{array}{l}8 \\
8 \\
0\end{array}$} & \multirow[t]{5}{*}{8} \\
\hline & Disagree & 8 & $\begin{array}{l}0 \\
i \\
i\end{array}$ & & & & & \\
\hline & Neutral & $\infty$ & $\stackrel{+}{\mathrm{d}}$ & & & & & \\
\hline & Agree & $\stackrel{\Xi}{=}$ & $\stackrel{0}{\dot{m}}$ & & & & & \\
\hline & $\begin{array}{l}\text { Strongly } \\
\text { agree }\end{array}$ & $\hat{o}$ & $\stackrel{a}{\grave{v}}$ & & & & & \\
\hline $\begin{array}{l}\text { You are } \\
\text { usually }\end{array}$ & $\begin{array}{l}\text { Strongly } \\
\text { disagree }\end{array}$ & 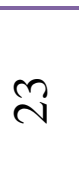 & : & $\ddot{\sigma}$ & 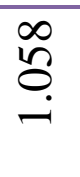 & $\begin{array}{l}\stackrel{\infty}{+} \\
\infty \\
0 \\
0\end{array}$ & $\stackrel{8}{8}$ & 15 \\
\hline
\end{tabular}




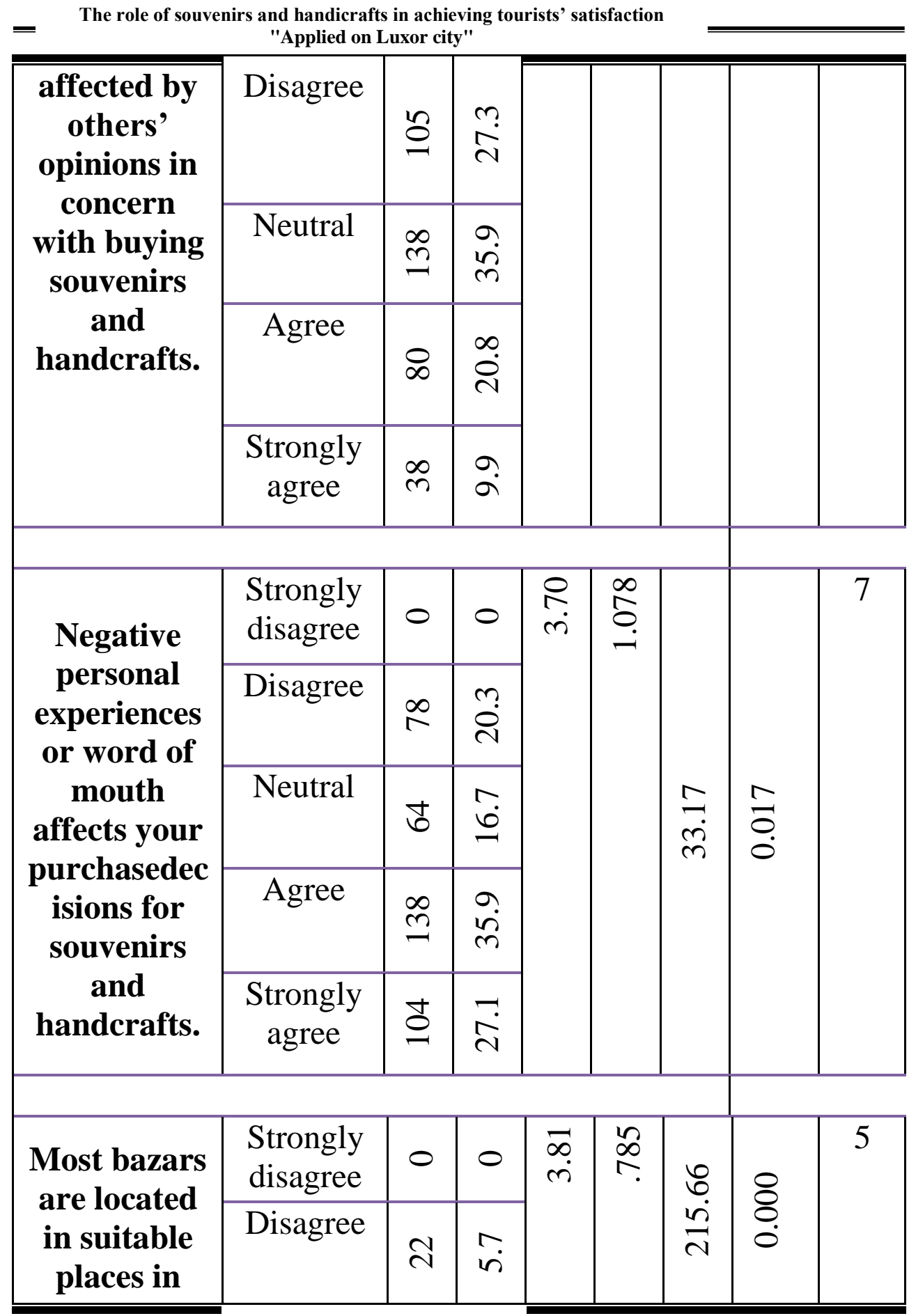




\begin{tabular}{|c|c|c|c|c|c|c|c|c|}
\hline & & & & \\
\hline \multirow[t]{4}{*}{ Luxor. } & Neutral & & & & & & & \\
\hline & & 2 & $\ddot{a}$ & & & & & \\
\hline & Agree & 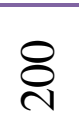 & $\vec{i}$ & & & & & \\
\hline & $\begin{array}{c}\text { Strongly } \\
\text { agree }\end{array}$ & ஜ & $\stackrel{1}{I}$ & & & & & \\
\hline & & & & & & & & \\
\hline \multirow{5}{*}{$\begin{array}{c}\text { Visiting } \\
\text { bazars gives } \\
\text { you } \\
\text { pleasure } \\
\text { and } \\
\text { satisfaction } \\
\text { through } \\
\text { your trip. }\end{array}$} & $\begin{array}{l}\text { Strongly } \\
\text { disagree }\end{array}$ & $\simeq$ & $\vec{m}$ & \multirow[t]{5}{*}{$\stackrel{f}{f}$} & \multirow[t]{5}{*}{$\underset{0}{g}$} & \multirow{5}{*}{$\begin{array}{l}\vdots \\
\vdots \\
\vdots \\
\vdots\end{array}$} & \multirow{5}{*}{$\begin{array}{l}8 \\
0 \\
0\end{array}$} & \multirow[t]{5}{*}{10} \\
\hline & Disagree & $n$ & $\stackrel{\infty}{\oplus}$ & & & & & \\
\hline & Neutral & I & 官 & & & & & \\
\hline & Agree & 0 & $\begin{array}{l}\infty \\
\dot{i} \\
\dot{i}\end{array}$ & & & & & \\
\hline & $\begin{array}{c}\text { Strongly } \\
\text { agree }\end{array}$ & $\stackrel{r}{r}$ & $\stackrel{m}{a}$ & & & & & \\
\hline & & & & & & & & \\
\hline \multirow{3}{*}{$\begin{array}{c}\text { Your } \\
\text { complains } \\
\text { are handled } \\
\text { seriously, } \\
\text { properly } \\
\text { and in a } \\
\text { proper time. }\end{array}$} & $\begin{array}{l}\text { Strongly } \\
\text { disagree }\end{array}$ & 0 & $\stackrel{0}{-}$ & \multirow[t]{3}{*}{$\stackrel{\ddot{n}}{n}$} & \multirow[t]{3}{*}{ ஜ } & \multirow{3}{*}{$\begin{array}{l}\infty \\
\infty \\
+\end{array}$} & \multirow{3}{*}{8} & \multirow[t]{3}{*}{13} \\
\hline & Disagree & $\hat{n}$ & $\stackrel{0}{a}$ & & & & & \\
\hline & Neutral & $\ddot{\sim}$ & $\frac{1}{6}$ & & & & & \\
\hline
\end{tabular}




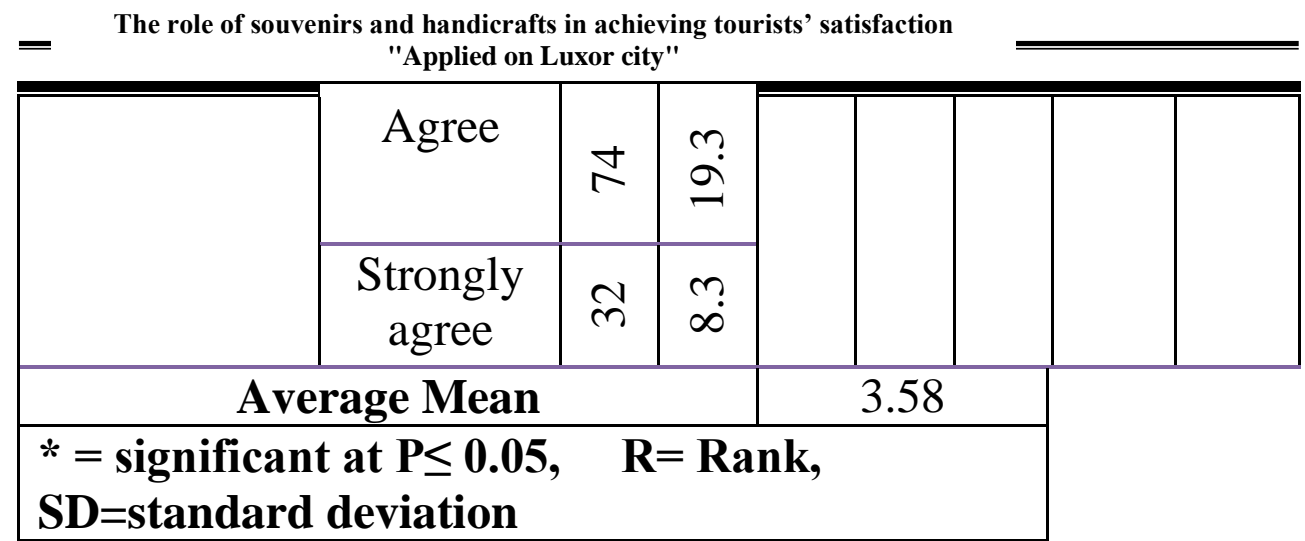

It is noticed from table (8) that the mean reveals to the degree of respondents' agreement about previous statements. The standard deviation reveals the harmony of respondents' opinions. The (t-test) p-value shows a significant for the mean and the standard deviation. Data presented in table (8) revealed that there was a significant difference among respondents' answers ( $\mathrm{p}<$ $0.05)$

Results in table (8) illustrated that the responses of research sample agree with the following statements according to the mean, the following statements has the highest level of agreement as follows"You are always keen to buy souvenirs and handcrafts that remind you of the destination were characterized by high level of agreement (mean $=4.26 \& \quad \mathrm{SD}=.83$ ). Furthermore,the statement of "Souvenirs and handcrafts that reflect destination's cultural heritage are the most attractive for you) by (Mean= 4.25), followed by the statement of "Prices of souvenirs and handcrafts differ widely from one bazar to another) by $($ Mean= 4.20). The statement of (Bazars' staff and employees are friendly and helpful) comes next by (Mean=3.93), followed by the statement of "Most bazars are located in suitable places in Luxor) by (Mean= 3.81). Regarding the statement of (Negative personal experiences or word of mouth affects your purchasedecisions for souvenirs and handcrafts) comes next by $($ Mean= 3.70).Finally the statement of "Scam exposure affects negatively your trip) by (Mean=3.65). 
Moreover, they were neutral on the following statements in order as follow;the statement of "You have suffered from crowdness during buying souvenirs and handcrafts) by (Mean= 3.55), then the statement of "Visiting bazars gives you pleasure and satisfaction through your trip) by (Mean= 3.45).Regarding the statement of "You have suffered from different ways of hassle forcing you to buy souvenirs and handcrafts at bazars) comes next by $($ Mean= 3.45), followed by the statement of "Buying souvenirs and handcrafts represent a great priority as a part of your trip) by (Mean= 3.25).For the statement of "Your complains are handled seriously, properly and in a proper time) is with $($ Mean= 3.23), then the statement of "You have been scammed during buying souvenirs and handcrafts) by (Mean= 3.03).The statement of "You are usually affected by others' opinions in concern with buying souvenirs and handcrafts) has $($ Mean= 3.01).Finally, the statement of "Prices of souvenirs and handcrafts are displayed clearly on each item in the bazar) by $($ Mean $=2.77)$.

Table (9): Putting budget for buying souvenirs and handcrafts

\begin{tabular}{|l|l|l|l|l|}
\hline Factor & Variables & Frequency & $\begin{array}{l}\text { Percentage } \\
(\%)\end{array}$ & Rank \\
\hline $\begin{array}{l}\text { Do you usually } \\
\text { determine } \\
\text { certain } \\
\text { (specific) } \\
\text { budget for } \\
\text { buying } \\
\text { souvenirs and } \\
\text { handcrafts? }\end{array}$ & Yes & 167 & $43.5 \%$ & 1 \\
\cline { 2 - 5 } & No & 217 & $56.5 \%$ & 2 \\
\hline Total & 384 & $100 \%$ & - \\
\hline
\end{tabular}


The role of souvenirs and handicrafts in achieving tourists' satisfaction

"Applied on Luxor city"

From the tabulated data of table (9), it could be noticed that the majority of respondents $56.5 \%$ of the research sample don't put specific budget for buying souvenirs and handcrafts, meanwhile $43.5 \%$ consider buying souvenirs and handcrafts and put a specific budget for buying them from the visited destination.

Table (10): Kind of scam in Luxor - if present

\begin{tabular}{|l|l|l|l|l|}
\hline Factor & Variables & Frequency & $\begin{array}{l}\text { Percentage } \\
(\%)\end{array}$ & Rank \\
\hline \multirow{2}{*}{$\begin{array}{l}\text { If you } \\
\text { have been } \\
\text { scammed } \\
\text { in Luxor }-\end{array}$} & $\begin{array}{l}\text { Incorrect } \\
\text { Information }\end{array}$ & 161 & $41.9 \%$ & 1 \\
\cline { 2 - 5 } $\begin{array}{l}\text { What kind } \\
\text { of scam } \\
\text { did you } \\
\text { face? }\end{array}$ & PriceScam & 147 & $38.3 \%$ & 2 \\
\cline { 2 - 5 } & Ouality Scam & 70 & $18.2 \%$ & 3 \\
\hline Total & Robbery & 0 & $1.6 \%$ & 4 \\
\hline
\end{tabular}

*Others responses were "I do not remember"

The results state clearly that the responses of the research sample on the kind of scam they have faced were as follows: $41.9 \%$ of the respondents their answers were (Incorrect information), 38.3\% their answers were (Price scam), $18.2 \%$ their answers were (Quality scam) while $1.6 \%$ their answers were(Others)and their answer were "I do not remember". Finally0\% their answers were robbery which clarifies that they haven't exposed to any kind of robbery.

Table (11): Buying souvenirs and handcrafts to friends and family

\begin{tabular}{|l|l|l|l|l|}
\hline Factor & Variables & Frequency & $\begin{array}{l}\text { Percentage } \\
(\%)\end{array}$ & Rank \\
\hline
\end{tabular}




\begin{tabular}{|c|c|c|c|c|}
\hline \multicolumn{5}{|c|}{ - عدد 0- يوثيو 19 +r } \\
\hline \multirow{2}{*}{$\begin{array}{l}\text { Do you buy } \\
\text { souvenirs and } \\
\text { handcrafts to } \\
\text { your friends } \\
\text { and family? }\end{array}$} & Yes & 329 & $85.7 \%$ & 1 \\
\hline & No & 55 & $14.3 \%$ & 2 \\
\hline \multicolumn{2}{|l|}{ Total } & 384 & $100 \%$ & - \\
\hline
\end{tabular}

The results clarifies that $85.7 \%$ of the respondents buy souvenirs and handcrafts to friends and family and on the other hand $14.3 \%$ of the respondents don't care about this issue.

Table (12): Positive or negative word of mouth to family, friends and other people

\begin{tabular}{|l|l|l|l|l|}
\hline Factor & Variables & Frequency & $\begin{array}{l}\text { Percentage } \\
(\%)\end{array}$ & Rank \\
\hline $\begin{array}{l}\text { Are you } \\
\text { always talk } \\
\text { about your } \\
\text { positive or } \\
\text { negative } \\
\text { buying } \\
\text { experience to } \\
\text { your family, } \\
\text { friends and } \\
\text { other people } \\
\text { you know? }\end{array}$ & Yes & 306 & $79.7 \%$ & 1 \\
\hline Notal & 78 & $20.3 \%$ & 2 \\
\hline
\end{tabular}


The role of souvenirs and handicrafts in achieving tourists' satisfaction "Applied on Luxor city"

The results shows that $79.7 \%$ of the respondents always talk about their positive or negative buying experience to their family, friends and other people while only $20.3 \%$ of the respondents don't mention it.

\section{Third: Relational Analysis}

Table (13): Correlations between research dimensions and tourists' satisfaction

\begin{tabular}{|c|c|c|c|}
\hline & & \begin{tabular}{|c|} 
Bazars' \\
Staff \\
Treatment \\
\end{tabular} & $\begin{array}{l}\text { Tourists' } \\
\text { Satisfaction }\end{array}$ \\
\hline $\begin{array}{l}\text { Bazars' Staff } \\
\text { Treatment }\end{array}$ & $\begin{array}{l}\text { Pearson } \\
\text { correlation } \\
\text { Sig. (2- } \\
\text { tailed) } \\
\mathrm{N}\end{array}$ & $\begin{array}{l}1 \\
384\end{array}$ & $\begin{array}{l}.849 \\
.000 \\
384\end{array}$ \\
\hline $\begin{array}{l}\text { Tourists' } \\
\text { Satisfaction }\end{array}$ & $\begin{array}{l}\text { Pearson } \\
\text { correlation } \\
\text { Sig. (2- } \\
\text { tailed) } \\
\mathrm{N}\end{array}$ & $\begin{array}{l}.849 \\
.000 \\
384\end{array}$ & $\begin{array}{l}1 \\
384\end{array}$ \\
\hline & & Crowd & \begin{tabular}{|l|} 
Tourists' \\
Satisfaction
\end{tabular} \\
\hline Crowd & $\begin{array}{l}\text { Pearson } \\
\text { correlation } \\
\end{array}$ & 1 & .764 \\
\hline & Sig. (2-tailed) & & .001 \\
\hline & $\mathrm{N}$ & 384 & 384 \\
\hline \multirow{3}{*}{$\begin{array}{l}\text { Tourists' } \\
\text { Satisfaction }\end{array}$} & $\begin{array}{l}\text { Pearson } \\
\text { correlation }\end{array}$ & .764 & .1 \\
\hline & Sig. (2-tailed) & .001 & \\
\hline & $\mathrm{N}$ & 384 & 384 \\
\hline & & Hassle & $\begin{array}{l}\text { Tourists' } \\
\text { Satisfaction }\end{array}$ \\
\hline Hassle & $\begin{array}{l}\text { Pearson } \\
\text { correlation }\end{array}$ & 1 & .575 \\
\hline
\end{tabular}




\begin{tabular}{|c|c|c|c|}
\hline \multicolumn{3}{|c|}{ 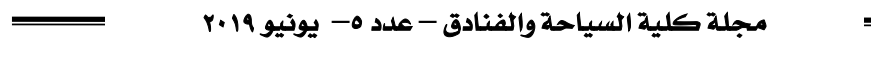 } & \multirow[b]{2}{*}{.000} \\
\hline & Sig. (2-tailed) & & \\
\hline & $\bar{N}$ & 384 & 384 \\
\hline \multirow{5}{*}{$\begin{array}{l}\text { Tourists' } \\
\text { Satisfaction }\end{array}$} & Pearson. & .575 & 1 \\
\hline & correlation & & \\
\hline & Sig. (2-tailed) & .000 & \\
\hline & $\mathrm{N}$ & 384 & 384 \\
\hline & & Scamming & $\begin{array}{l}\text { Tourists' } \\
\text { Satisfaction }\end{array}$ \\
\hline \multirow[t]{2}{*}{ Scamming } & $\begin{array}{l}\text { Pearson } \\
\text { correlation }\end{array}$ & 1 & .828 \\
\hline & $\begin{array}{l}\text { Sig. (2-tailed) } \\
\mathrm{N}\end{array}$ & 384 & $\begin{array}{l}.000 \\
384\end{array}$ \\
\hline \multirow[t]{2}{*}{$\begin{array}{l}\text { Tourists' } \\
\text { Satisfaction }\end{array}$} & $\begin{array}{l}\text { Pearson } \\
\text { correlation } \\
\text { Sig. }(2- \\
\text { tailed) } \\
\mathrm{N}\end{array}$ & \begin{tabular}{|l}
.828 \\
.000 \\
384
\end{tabular} & $\begin{array}{l}.1 \\
384\end{array}$ \\
\hline & & $\begin{array}{l}\text { Product } \\
\text { variety }\end{array}$ & $\begin{array}{l}\text { Tourists' } \\
\text { Satisfaction }\end{array}$ \\
\hline \multirow[t]{3}{*}{ Product variety } & $\begin{array}{l}\text { Pearson } \\
\text { correlation }\end{array}$ & 1 & .758 \\
\hline & Sig. (2-tailed) & & .000 \\
\hline & $\mathrm{N}$ & 385 & 385 \\
\hline \multirow[t]{3}{*}{$\begin{array}{l}\text { Tourists' } \\
\text { Satisfaction }\end{array}$} & $\begin{array}{l}\text { Pearson } \\
\text { correlation }\end{array}$ & .754 & .1 \\
\hline & Sig. (2-tailed) & .000 & \\
\hline & $\mathrm{N}$ & 384 & 384 \\
\hline
\end{tabular}

**Correlation is significant at the 0.01 level (2-tailed).

As seen in table (13),there is a positive and significant relationshipbetween the above mentioned questions and tourists' satisfaction. Results showed that the Pearson correlation between bazars' staff treatment and tourists' satisfaction is 0.849 . at the 0.001 significance level.Moreoverthe value of correlation betweencrowd and tourists' satisfaction is 0.764 . at the 0.001 significance level. The same table clarifies that the value of correlation betweenhassle and tourists' satisfaction is 0.575 . at 
- The role of souvenirs and handicrafts in achieving tourists' satisfaction "Applied on Luxor city"

the 0.001 significance level. Regarding the value betweenscamming and tourists' satisfaction is 0.828 . at the 0.001 significance level.Finally it is 0.758 between product variety and tourists' satisfaction at the 0.001 significance level.

Table (14): Research dimensions influencing tourists' satisfaction (TS)

\begin{tabular}{|c|c|c|c|c|c|}
\hline \multirow{2}{*}{$\begin{array}{l}\text { Bazars' Staff } \\
\text { Treatment }\end{array}$} & \multicolumn{3}{|c|}{ Un-standardized coefficients } & \multirow{2}{*}{$\begin{array}{l}\text { Sig. } \\
.000 \\
\end{array}$} & \multirow{2}{*}{\begin{tabular}{|l|} 
Model \\
statistic \\
$\mathrm{s}$
\end{tabular}} \\
\hline & B & Std. Error & R-sql & & \\
\hline Constant & $.989 *$ & .159 & \multirow[t]{2}{*}{.721} & .000 & \multirow{2}{*}{$\begin{array}{l}\mathrm{F}: \\
25.338 \\
2\end{array}$} \\
\hline $\begin{array}{l}\text { Tourists' } \\
\text { Satisfaction }\end{array}$ & $.706^{*}$ & .044 & & .000 & \\
\hline \multirow[t]{2}{*}{ Hassle } & \multicolumn{3}{|c|}{ Un-standardized coefficients } & Sig. & $\begin{array}{l}\text { Model } \\
\text { statistic } \\
\text { S }\end{array}$ \\
\hline & B & Std. Error & R-square & .000 & \multirow{3}{*}{$\begin{array}{l}\mathrm{F}: \\
20.7 \\
018 \\
\end{array}$} \\
\hline Constant & $1.102 * *$ & .178 & \multirow{2}{*}{.584} & .000 & \\
\hline $\begin{array}{l}\text { Tourists' } \\
\text { Satisfaction }\end{array}$ & $.715^{* *}$ & .050 & & .000 & \\
\hline \multirow[t]{2}{*}{ Crowd } & \multicolumn{3}{|c|}{ Un-standardized coefficients } & Sig. & $\begin{array}{l}\text { Model } \\
\text { statistic } \\
\mathrm{S}\end{array}$ \\
\hline & $\mathrm{B}$ & Std. Error & R-square & .000 & \multirow{3}{*}{$\begin{array}{l}\mathrm{F}: \\
77.7 \\
253 \\
\end{array}$} \\
\hline Constant & $1.170 * * *$ & .255 & \multirow{2}{*}{.330} & .000 & \\
\hline $\begin{array}{l}\text { Tourists' } \\
\text { Satisfaction }\end{array}$ & $.638 * * *$ & .071 & & .000 & \\
\hline \multirow[t]{2}{*}{ Scamming } & \multicolumn{3}{|c|}{ Un-standardized coefficients } & Sig. & $\begin{array}{l}\text { Model } \\
\text { statistic } \\
\mathrm{S}\end{array}$ \\
\hline & $\mathrm{B}$ & Std. Error & R-squ & .000 & \multirow{3}{*}{$\begin{array}{l}\mathrm{F}: \\
23.85\end{array}$} \\
\hline Cons & $.696^{*}$ & .180 & \multirow[t]{2}{*}{.575} & .000 & \\
\hline Tourists' & $.663 * * * *$ & .050 & & .000 & \\
\hline
\end{tabular}




\begin{tabular}{|c|c|c|c|c|c|}
\hline \\
\hline Satisfaction & & & & & 64 \\
\hline \multirow{2}{*}{$\begin{array}{l}\text { Product } \\
\text { variety }\end{array}$} & \multicolumn{3}{|c|}{ Un-standardized coefficients } & Sig. & Model \\
\hline & $\mathrm{B}$ & Std. Err & R-squ & .000 & \multirow{3}{*}{$\begin{array}{l}F: \\
17.8 \\
876\end{array}$} \\
\hline Constant & $.543 * * * *$ & .349 & .686 & .000 & \\
\hline $\begin{array}{c}\text { Tourists } \\
\text { Satisfaction }\end{array}$ & $.651 * * *$ & .07 & & .000 & \\
\hline
\end{tabular}

* Regression equation can be formed as bazars' staff treatment $=.989+.706 \mathrm{TS}$

$* *$ Regression equation can be formed as hassle $=1.102+$ .715 TS

$* * *$ Regression equation can be formed as crowd $=1.170+$ .638TS

$* * * *$ Regression equation can be formed as scamming $=$. $.696+.663 \mathrm{TS}$

$* * * * *$ Regression equation can be formed as product variety $=.543+.651 \mathrm{TS}$

A regression analysis in table (14) has created to determine whichsouvenirs and handcrafts dimensions affect tourists' satisfaction. When assessing the degree of influence for each dimension of souvenirs and handcraftson tourists' satisfaction based on the previously mentioned correlation results. Bazars' staff treatmentwas found to be significantly influence tourists' satisfaction (R-square $=.721$, P-value $=.000)$. Furthermore, (Product variety) R-square=.686, P-value=.000; (Hassle) R-square $=.584$, P-value $=.000$; (Scamming) Rsquare $=.575, \quad \mathrm{P}$-value $=.000 ; \quad($ Crowd $) \quad \mathrm{R}$-square $=.330, \quad \mathrm{P}$ value $=.000]$ were found to be significantly affect tourists' satisfaction respectively.

\section{Conclusions:}

1- $\quad$ By assessing the dimensions that influence souvenirs and handcrafts on tourists' satisfaction, it was found that bazars' staff 
- The role of souvenirs and handicrafts in achieving tourists' satisfaction

"Applied on Luxor city"

treatment is the main element that influences their satisfaction as they are affected greatly by the helpfulness and the friendly treatment of the personnel and sellers. Product variety comes next as they got satisfied by finding all what they need in one place. They also got disturbed by hassle of some sellers and their aggressive attitude of pushing them to buy, followed by scamming especially by providing them with incorrect information and also the conflict in price of souvenirs that differ from one place to another.Crowd of bazars comes next as they got annoyed when they can't be able to walk freely to buy what they need.

2- The overall findings of this study indicate the importance of tourists' visiting bazars and souvenirs retailers as a fundamental part of their itinerary in any destination. They are also keen to know the souvenirs distinguishing this destination before purchase. They always insist on buying souvenirs and handcrafts that remind them with it and serve as a momento that reconnect them to experiences which related to this destination. These findings are consistent with the studies ofMorgan and Pritchard (2005), (Swanson,K., and Timothy, D., 2012), (Trinh, T.et al. 2014), (Paraskevaidis, P., and Andriotis, K., 2015), Singh (2017), (Marangkun, W. and Thipjumnong, A., 2018) and Shtudiner et al. (2019).

Tourists buy souvenirs and handcrafts not only for them but also keen on buying these products to give to friends and relatives after returning back home, this is aligned with the study of Dumbrovska and Fialova (2019).

Previous results indicate the importance of visiting destination's bazars and its effect on tourists' overall satisfaction and also clarify that this small memory becomes a continuous promoting tool for this destination.

3- Tourists are more attracted to souvenirs and handcrafts that reflect the destination's cultural heritage. This is because that 
these products distinguish this destination from others as they reflect the uniqueness and authenticity in which created by local citizens. This is referred in the study of (Smith, H., 1987).

4- $\quad$ There is a positive and significant relationship between bazars' staff treatment, scamming, crowd, product variety and hassle with tourist's' satisfaction. As the treatment of personnel and sellers at bazars is the most correlated element that affect their satisfaction.

5- Most of tourists have been suffered from Scam by providing them with incorrect information (41.9\%) and (38.3\%) have been suffered from price scam. They have stated that there is conflict in prices from one bazar to another which causes dissatisfaction. Moreover, there were no price tags displayed on the souvenirs in addition to hassle pushing them to buy such souvenirs. Others with $(18.2 \%)$ have suffered from quality scam as they have get disappointed after knowing real prices for souvenirs in comparison with their values. (Sahartanto, D., 2016) has mentioned this.

6- $\quad$ Tourists have stated that negative personal experiences and word of mouth have affected their purchase decisions for souvenirs and handcrafts. Results also have revealed that (79.7 $\%$ ) transfer their positive or negative experience to others after returning back home. This indicates the importance of getting a satisfied tourist to assure his revisit and transfer his positive shopping experience to others regarding purchasing from bazars and souvenirs retailers.

\section{Recommendations:}

The Egyptian Chamber of Touristic Commodities has to buildan integrated database for bazars and souvenirs retailers with their sellers and personnel working.It also has to offer 
- The role of souvenirs and handicrafts in achieving tourists' satisfaction

"Applied on Luxor city"

training courses to them to ensure that they are going to provide a distinctive service to tourists. Tight control is also required to be sure that they provide correct information to tourists and also display clearly prices on each product by at least two different languages. Moreover, continuous inspectionis essential to assure that all opened bazars are licensed. In addition, it has to promote for products that reflect the local and cultural heritage of the destination rather than relying on Chinese ones.

Bazars personnel and sellers always have to clarify to tourists the difference between hand-made souvenirs and mass produced ones whichare not Egyptian made, they are just products having the logo or the photo of the sightseeing on them. 
${ }^{1}$ Lecturer of Tourism management- Faculty of Tourism and Hotels - Luxor University

${ }^{2}$ Ass.Prof of Tourism management- Faculty of Tourism and Hotels - Mansoura University

\section{References:}

1. Abrudan, I.N., and Dabija, D., (2014). Measuring clients' satisfaction towards Procedia Economics and Business, 15, P 1243- 1252.shopping centers; empirical evidence from Romania".

2. Amaro, S., Morgado Ferreira, B., \& Henriques, C. (2019). Towards a deeper understanding of the purchase of souvenirs. Tourism and Hospitality Research, 0(0) 1-14.

3. Anuar, A., and Haron, N., (2017). Souvenirs; Purchase among tourist perspectives in national park, Journal of Tourism Hospitality, 6 (3), P 287.

4. Barutucus, S., Dogan, H., and Unguren, E., (2011).Tourist perception and satisfaction of shopping in Alanya Region; A comparative analysis of different nationalities, Procedia of social and behavioral science, 24, P 1049- 1059.

5. Beigpoor, R., (2012).Factors that influence tourist satisfaction,Journal of Travel and Tourism research, Destination Management special issue, $\mathrm{P} 33$.

6. Cai,L., Lehto, X., and O'Leary, J., (2001).Profiling the USbound Chinese travelers by purpose of trip,Journal of Hospitality and Leisure Marketing, 7, p 3-17.

7. Cohn, E., (1995).Touristic craft ribbon development in Thailand,Journal of Tourism Management, 16 (3), P225-235. 
8. Corte, V., Sciarelli, M., Cascella, C., and Gaudio, G., (2015).Customer satisfaction in tourist destination; The case of tourism offer in the city of Naples, Journal of Investment and Management, 4 (4), P 39-50.

9. Dumbrovska , V., and Fialova,D., (2019), The city of one hundred souvenir shops:authenticity of souvenirs in Prague, Journal of Tourism and Cultural Change, doi.org/10.1080/14766825.2019.1606228.

10. Durie, A., and Kebede, A., (2017).Determinants of tourist satisfaction; evidence from tourist destination sites, in Amhar Region, Ethiopia. Singaporean journal of Business economics and management studies, 5 (8).

11. Gasana, P., (2009).Relative status and interdependent effects in consumer behavior,Journal of socio-economics, 38, P 52-59.

12. Goeldner, R., Ritchie, J. and McIntosh, R., (2000).Tourism, principles, practices, philosophies, NewYork, John Wiley \& Sons publication, P 270-294.

13. Goo,Y., and Shen, M., ( 2011).The relationship between authenticity and the souvenir purchase intent, Pan-Pacific Management review, 14(2), P 109-129.

14. Gordon, B., (1986). The souvenir:Messenger of the extraordinary, Journal of popular culture, 20 (3), P 135.

15. Heung, V.C., and Cheng, E., (2000).Assessing tourists' satisfaction with shopping in the Hong Kong special administrative region of china,Journal of Travel research, 38, P 396-404.

16. Khairannisa, H., Wyuniaiti, K., and Hurmayani, E., (2016).Assessing tourist shopping satisfaction in the Pasar Beringharo, Yogyakarta using importance performance 
analysis,Journal of Tourism, Leisure, and Global change, 3, P.Toc-33.

17. Kim, S., and Littrell,M.A., ( 1999).Predicting souvenir purchase intentions, Journal of Travel Research, 38, P 153.

18. Lehew, M.L.A., and Wesely, S.C., (2007).Tourist shopper satisfaction with regional shopping mall experiences,Culture, Tourism, and Hospitality research, 1 (1), P 82-96.

19. Littrell, M.A., Baizerman,S., Kean,R., Gahning,S., Neimeyer, S., Reilly, R., and Stout, J., (1994).Souvenirs and Tourism styles, Journal of Travel Research, 33 (1), P3-11.

20. Littrell, M.A., Luella, F.A., and Pamela, J., (1993).What makes a craft souvenir authentic?, Annals of Tourism Research, 20, P 197- 215.

21. Magindol,S., and Hassand, A., (2014).Tourists' perceptions about and appealing handicraft,Journal of Tourism Leisure and Global Change, 1, p.Toc-10, P 12.

22. Marangkun,W., and Thipjumnong, A., (2018). Souvenir product purchasing as a travel motivation in the shopping area of ThaleNoi, Phatthalung, Thailand",Journal of Tourism and Hospitality Management, 6 (2), P 47- 60.

23. Markwick,M.C., (2001).Tourism and the development of handicraft production in the Maltese island, Journal of Tourism geographies, 3 (1), P.29-51.

24. Morgan, N., and Pritchard,A., (2005).On souvenirs and metonymy narratives of memory, metaphor and materiality, Journal of Tourist Studies, 5 (1), P 29-53.

25. Moscardo, G., (2004).Shopping as a destination attraction; An empirical examination of the role of shopping in tourists' 
destination choice and experience,Journal of Vacation Marketing, 10 (4), P 294-295.

26. Ola Lcre, F.E., (2017).Importance of product attributes for souvenir purchase preferences; A view point of foreign tourists in south Africa, African Journal of Hospitality, Tourism and Liesure,6 (3).

27. Paraskevaidis, P., and Andriotis, K.,(2015).Values of souvenirs as commodities, Journal of Tourism Management, 48, P 6.

28. PenerLiev, M. (2012). The souvenir industry as an additional tourist activity, Multi disciplinary research journal,www.quaestus.ro/wp-content/uploads/2012/03/MilenPENERLIEV.pdf, last access 24/5/2019 .P 67-72.

29. Roostika, R., Wahyuningsih,T., and Haryono,S., (2015).The impacts of external competitiveness factors in the handicrafts industry,Polish Journal of Management, 12 (1), P 122-135.

30. Schluter, R., (1998). The role of T-shirts in the creation of Tourist destination images, Estudios perspectives en Turismo, 7 , P 5-23.

31. Shtudiner, Z., Klein, G., Zwilling, M., and Kantor, J. (2019). The value of souvenirs: Endowment effect and religion. Annals of Tourism Research, 74, P.17-32.

32. Singh, M., (2017).Community perspective on role of souvenirs in Tourism promotion- A case study of Basholi, Jammu, J and K,Journal of Business and Management, 19 (11), P 28-33. tourists: 
Conceptualframework,Journal of Tourism Intelligence and smartness, Issue 1, P.75-87.

34. Smith, H., (1987).Four kinds of Tourism,Annals of Tourism Research, 14, P332-344.

35. Suhartanto, D. (2016). Tourist satisfaction with souvenir shopping: evidence from Indonesian domestic tourists. Current Issues in Tourism, 21(6), 663-679.

36. Sthapit, E. (2018). The more the merrier: Souvenir shopping, the absence of choice overload and preferred attributes. Tourism Management Perspectives, 26, P.126-134.

37. Swanson, K.K., (2004).Tourists' and retailers' perception of souvenirs, Journal of Vacation Marketing, 10 (4), P 364.

38. Swanson, K.K. and Timothy, D.J., (2012).Souvenirs: Icons of meaning. Commercialization, Journal of Tourism Management, 33 (3), P 489 - 499.

39. Thompson, F., Hannah, K., and Petrie, K., (2012).Producing ceramic art work through tourism research,Annals of Tourism Research, 39 (1), P 336- 360.

40. Trinh, T.T., Ryan, C., and cave, J., (2014).Souvenir sellers and perceptions of authenticity-The retailers of Hoi An Vietnam, Journal of Tourism Management, 45, P. 275-283.

41. Wei, W. (2018). Understanding values of souvenir purchase in the contemporary Chinese culture: A case of Shanghai Disney. Journal of Destination Marketing and Management, 10, P. 36-48. 42. Wilkins, H., (2010).Souvenirs; What and Why we buy?,Journal of Travel Research, https:llwww.researchgate.net publication 249701268, last access 241512019.

43. Wong, I.A., and Wan, Y.K., (2013).A systematic approach to scale development in tourist shopping satisfaction,Linking 
destination attributes and shopping experiences,Journal of Travel Research, 52 (1), P 29- 41.

44. Zaho,L.,(2018), Study on the Development Strategy of Tourist Souvenirs in Changbai Mountain Nature Reserve, Advances in Economics, Business and Management Research, volume 71 . 